\title{
Risk Assessment of Monitoring Services using COBIT 5 Framework
}

\author{
Yuni Putri Andriani \\ Department of Information System \\ Universitas Ahmad Dahlan \\ Yogyakarta of Indonesia
}

\author{
Imam Riadi \\ Department of Information System \\ Universitas Ahmad Dahlan \\ Yogyakarta of Indonesia
}

\begin{abstract}
PT. Binokular Media Utama has used information technology assistance as a means of service, an information system to support business processes in the field of media monitoring to monitor the output of print, online and broadcast media in analytical activities. The information system used at PT. Binokular Media Utama is Bino Premium to manage data that will be displayed to clients, there are several risks that can interfere with monitoring activities of Bino Premium products to manage data in print, online and broadcast media. Risk management is carried out at PT. Binokular Media Utama using the COBIT 5 framework with the APO12 (Managing Risk) process consisting of APO12.01 to APO12.06 and EDM03 (Ensuring Risk Optimization) consisting of EDM03.01 to EDM03.02. The capability level assessment used in the process assessment is done by collecting observation data, interviews, and questionnaires and then analyzing the data using the Process Assessment Model so that it can determine the current capability value, expected capability value, gap value analysis, and determine recommendations for each risk. The assessment of the current capability level based on the results of the calculation of the APO12 process (Managing Risk) obtained a value of 3.67 which indicates the implementation of the process is at level 4 (Predictable Process) and EDM03 (Ensuring Risk Optimization) obtained a value of 3 which indicates the implementation of the process is at level 3 (Established Process). The results of the gap value (gap) based on calculations carried out with the APO12 process (Managing Risk) found a gap of 0.33 and EDM03 (Ensuring Risk Optimization) found a gap of 1 . The results of the gap discovery were used to make recommendations related to risk management in the company so as to achieve the company's expected future goals.
\end{abstract}

\section{Keywords}

Information Systems, Risk Management, COBIT 5, Process Capability Level.

\section{INTRODUCTION}

Every company has an information system to support business processes in the company to manage data and information needed by the company [14]. PT. Binokular Media Utama is a company engaged in the field of media monitoring to monitor the output of print, online and broadcast media in analysis activities. PT. Binokular Media Utama has used information technology assistance as a means of service. Monitoring services are used to monitor and control various business processes in project developers and operations. The information system at PT. Binokular Media Utama is Bino Premium for managing data to be displayed to clients. These systems are integrated with each other in one system. If a problem occurs, it will be easier to manage the existing data in print, online and broadcast media. Risks that can interfere with monitoring activities of Bino Premium products. Risk management is carried out using the COBIT 5 framework that focuses on APO12 (Managing Risk) and EDM03 (Ensuring Risk Optimization). APO12 (Managing Risk) aims to identify, assess and reduce risks related to information technology at the tolerance level set by the company's executive management. EDM03 (Ensuring Risk Optimization) aims to ensure that the company's risk appetite and tolerance are understood, articulated, and communicated, and the risks to company value associated with the use of information technology are identified and managed. Assessment of the level of process capability and the results of the gap value as well as recommendations for improvement of monitoring services at PT. Binokular Media Utama.

\section{STUDY LITERATURE}

\subsection{Definition of Analysis}

Analysis is an attempt to observe in detail by describing the activities of rational thought, the constituent components objectively applying the methodology to compose these components so that an assessment of the object is carried out to be studied more deeply into components that are still intact into smaller sub-components [17].

\subsection{Definition of Risk}

Risk is an event that occurs in a company that affects the achievement of company goals. Risk management is the ability to deal with risks with a good effect in helping to realize the goals of a company [20].

\subsection{Definition of IT Risk Management}

IT Risk Management is a combination of a process used to identify, review, develop prevention strategies and communicate IT risks that have an adverse effect and cause losses to the company [8].

\subsection{COBIT 5}

Control Objectives for Information and Related Technology (COBIT 5) is a framework to measure the quality of information technology governance to support the activity process to focus on the strategic value of information technology implementation (IT strategic value) and determine IT implementation to support the achievement of the company's vision and mission [2]. The COBIT 5 framework consists of 5 (five) main principles and is equipped with 7 (seven) enablers. COBIT 5 adapts 5 (five) principles that seem to companies that can create a successful governance and management framework with a holistic approach of 7 (seven) enablers provided so as to optimize technology and information while providing benefits to stakeholders [11]. 


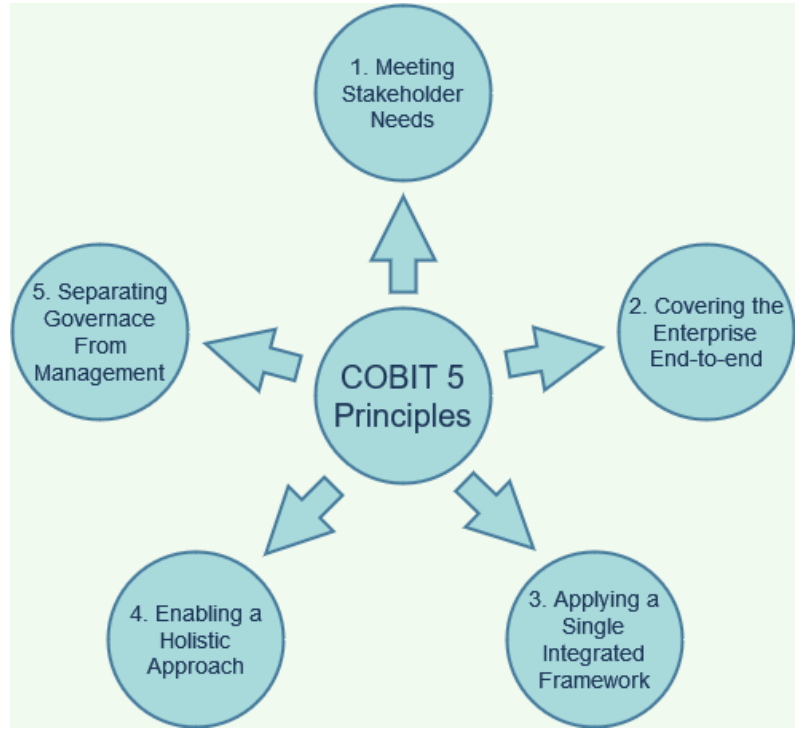

Figure 1. The Five Principles of COBIT 5

Based on Figure 1 there are 5 (five) main principles that must be carried out as follows:

1. Meeting Stakeholder Needs, undertakes all stakeholder needs in maintaining a balance to realize benefits and optimize risks.

2. Covering the Enterprise End-to-end, integrating information technology corporate governance from upstream to downstream.

3. Applying a Single Integrated Framework, applying a single integrated framework to provide guidance on a subset of information technology activities.

4. Enabling a Holistic Approach, enabling an efficient and effective holistic approach to corporate governance and management.

5. Separating Governance from Management, separating governance from management.

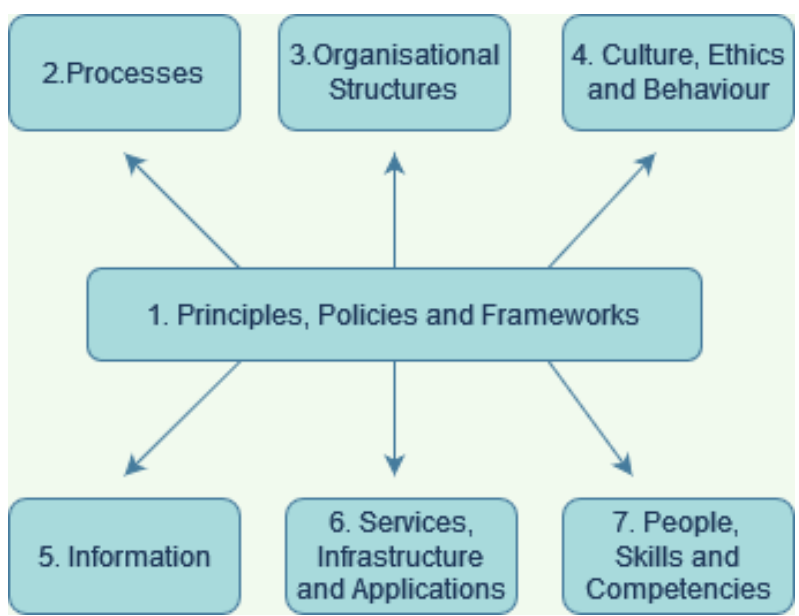

Figure 2. Seven Enablers COBIT 5

Based on Figure 2 there are 7 (seven) enablers of COBIT 5 as below:

1. Principles, Policies and Frameworks, formulate stakeholder needs as a guide that will be used in the company's operational activities in the field of information technology.

2. Processes, providing details of activities and activities carried out to achieve company goals.
3. Organisational Structures, meet the needs and objectives of stakeholders for decisions and policies made by the company.

4. Culture, Ethics and Behavior, provides an assessment of a company's habits and goals so that they can be achieved with good company habits.

5. Information, companies need information in carrying out business processes to make movements by making decisions and solving problems within the company.

6. Services, Infrastructure and Applications, providing services, infrastructure and applications for the company's information technology processes.

7. People, Skills and Competencies, carrying out all activities and making decisions with the right skills and competencies and successfully.

\subsection{Process Capability Level}

In the COBIT 5 framework, there are 6 (six) levels of process capability [11]

1. Level 0 (Incomplete Process), the process is not implemented or fails to achieve the goal of the process.

2. Level 1 (Performed Process), the implementation of the process achieves its objectives.

a. PA 1.1 Process Performance, the implemented process achieves its process objectives.

3. Level 2 (Managed Process), the process at level 1 is implemented into a process arrangement (planned, monitored, and evaluated) and the work products of the process are defined, controlled, and maintained appropriately.

a. PA 2.1 Performance Management, measures the extent to which process performance is managed.

b. PA 2.2 Work Product Management, measures the extent to which the work products produced by the process are managed appropriately.

4. Level 3 (Established Process), the process is defined and implemented according to existing standards.

a. PA 3.1 Process Definition, measures the extent to which a process is maintained to improve the deployment of a defined process.

b. PA 3.2 Process Deployment, measures the extent to which the process is still implemented as a defined process to achieve the results of the process.

5. Level 4 (Predictable Process), the process operates according to the specified limit to achieve the process results.

a. PA 4.1 Process Measurement, measures the extent to which the measurement results can ensure that the performance of the relevant process performance goals is achieved in support of the specified business objectives.

b. PA 4.2 Process Control, measures the extent to which processes are managed quantitatively to produce stable, capable, and predictable processes within specified limits.

6. Level 5 (Optimizing Process), processes are developed constantly to complement current 
conditions that are relevant and lead to business goals.

a. PA 5.1 Process Innovation, process Innovation, measures the extent to which process changes are identified from the implementation of the process and from the innovation approach to the implementation of the process.

b. PA 5.2 Process Optimization, measures the extent to which changes are defined, effectively manages process execution to support the achievement of process improvement objectives.

\subsection{RACI Chart}

RACI Chart has a function at the process level of responsibility for roles in the organizational structure of a company [1]. The RACI Chart defines the authority of a person in an IT-based company. The RACI Chart that will be used is guided by the APO12 and EDM03 processes, which will then be used to determine respondents.

There are 6 (six) key management practices of COBIT 5 as below:

1. APO12.01 (Collect Data), identify and collect data that is useful for identifying, analyzing, and reporting risks related to effective information technology.

2. APO12.02 (Analyze Risk), disseminate useful information to support decision making that is useful in business processes and risk factors that occur.

3. APO12.03 (Maintain a Risk Profile), maintain a list containing known risk and risk attributes and related resources, capabilities and control activities.

4. APO12.04 (Articulate Risk), provide information regarding explanations and opportunities regarding the latest information technology to all stakeholders needed to get the right response.

5. APO12.05 (Define a Risk Management Action Portfolio), manage existing opportunities to minimize all risks to an acceptable level as a portfolio.

6. APO12.06 (Respond to Risk), responding quickly in a short time with effective steps to reduce the magnitude of losses due to events related to information technology.

There are 2 (two) key governance practices of COBIT 5 as below:

1. EDM03.01 (Evaluate Risk Management), examine and make an assessment of the effect of risk on the use of the latest information technology in the company. Considering the appropriate corporate risk appetite and risks to company value associated with the use of information technology are identified and managed.

2. EDM03.02 (Direct Risk Management), establish risk management measures to provide adequate assurance regarding information technology risk management in accordance with ensuring that information technology risk does not exceed the risk appetite of the board of directors.

\subsection{Implementation of COBIT 5}

According to (ISACA, 2012) the implementation of COBIT 5 has 7 (seven) stages that need to be carried out as follows [12]:

1. What are the drivers? (Initiate Program), the first stage is carried out by starting who will build control over the control of change and recognize the need to implement the desired process.

2. Where are we now? (Define Problems and Opportunities), the second stage is carried out by defining the problems that occur related to risk and forming a strategy that is following the company's objectives in its implementation and assessing the current situation to determine process capability.

3. Where do we want to be? (Define Road Map), the third stage is done by determining the desired target and opening the path that must be passed to reach the desired level.

4. What needs to be done? (Plan Program), the fourth stage is carried out by planning what must be done to identify solutions that will be carried out and build improvements for implementation.

5. How do we get there? (Execute Plan), the fifth stage is carried out by implementing the plans that have been made in the fourth stage to use this method and implement the improvements that have been designed.

6. Did we get there? (Realize Benefit), the stage that is carried out by realizing the benefits that have been associated with changed management and have been improved through the measurement of process capabilities.

7. How do we keep the momentum going? (Review Effectiveness), the seventh stage is carried out by implementing what has been implemented and simplifying where the process runs.

\subsection{Process Assessment Model}

According to (ISACA, 2012) Process Assessment Model is used for process-based COBIT assessment in order to improve the accuracy and reliability of IT process assessment. Indicators are used to assess process attributes can be achieved or not. There are 2 (two) types of assessment indicators:

1. Process Capability Indicators, with capability levels 1 to 5 . This indicator is general for each process capability attribute. The indicators used to assess process capability are Generic Practice (GP) and Generic Work Products (GWP).

2. Process Performance Indicators, which apply exclusively to capability level 1. Process performance indicators (base practices and work products) are specified for each process and are used to determine whether the process capability is at level 1 .

\section{METHODOLOGY}

\subsection{Research Stage}

This research was conducted using the COBIT 5 framework for the APO12 (Managing Risk) and EDM03 (Ensuring Risk Optimization). The scenario that will be passed explains the stages of working on this research so that the steps are more focus and clear. 


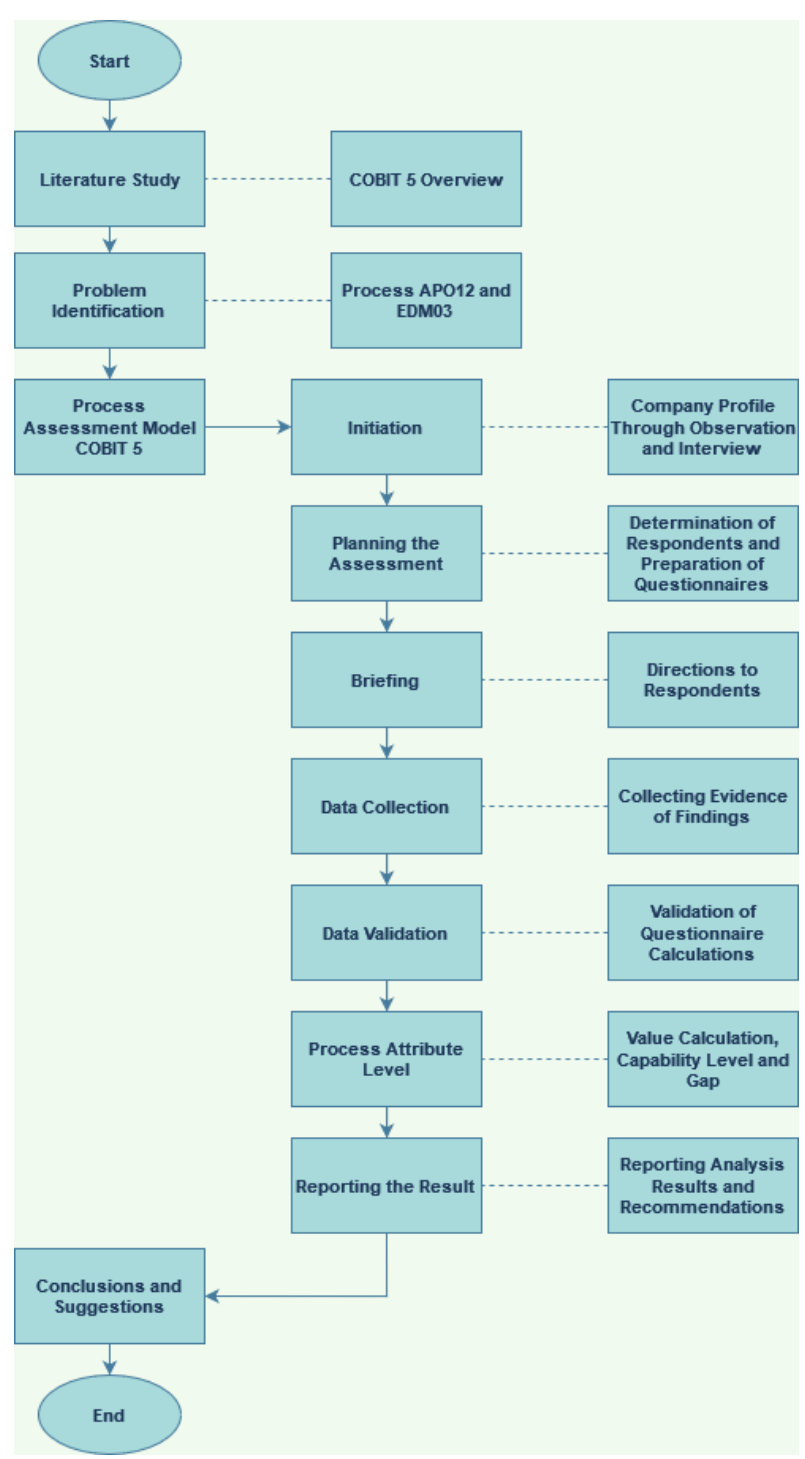

Figure 3. Stages of Research

Based on Figure 3, 11 (eleven) the stages of the research carried out are as below:

1. The first stage is looking for a literature study on the general description of the COBIT 5 framework by exploring reference information from previous research related to risk management carried out for the selection of domains in the COBIT 5 framework.

2. The second stage identifies problems that exist in the background. It has been explained to find out the existing problems and determine the right domain to solve the problem by using the APO12 and EDM03 processes.

3. The third stage applies the Process Assessment Model method in accordance with the COBIT 5 framework which consists of the stages of Initiation, Planning the Assessment, Briefing, Data Collection, Data Validation, Process Attribute Level, and Reporting the Result which are used to assess the level of process capability in COBIT 5.

4. The fourth stage is Initiation to find out the general description of the company and information related to the company profile, company vision and mission, company organizational structure, and company business processes obtained from the results of data collection through observations and interviews.

5. The fifth stage is Planning the Assessment to determine respondents who are in accordance with the responsibilities within the company who will fill out the questionnaire guided by using the RACI Chart APO12 and RACI Chart EDM03 and compiling a questionnaire in the form of a series of questions that have been adapted to the COBIT 5 framework in the APO12 process (Managing Risk) and the EDM03 process (Ensuring Risk Optimization).

6. The sixth stage is conducting a briefing to provide information on the direction of research conducted to respondents regarding data collection from responsible and knowledgeable sources related to the use of information technology in the company.

7. The seventh stage is conducting Data Collection to obtain evidence related to the process assessment of each activity in the APO12 (Managing Risk) and EDM03 (Ensuring Risk Optimization) processes as evidenced by data collection findings that have been carried out in research.

8. The eighth stage is conducting Data Validation to validate the results of the questionnaire derived from respondents' answers which are used to determine the capability level of the APO12 (Managing Risk) and EDM03 (Ensuring Risk Optimization) processes.

9. The ninth stage is conducting Process Attribute Level to show the results of the process capability from the questionnaire calculation to determine the level of APO12 (Risk Management) and EDM03 (Ensuring Risk Optimization) process capabilities and perform gap analysis.

10. The tenth stage is conducting Reporting the Result to report the results of the analysis and provide recommendations obtained through the results of the risk assessment that has been carried out in the research.

11. The eleventh stage makes conclusions from the research which contains a summary of the results of the research process that has been carried out, in order to answer the formulation of the problem and the objectives of the research.

\subsection{Method of Collecting Data}

1. Observations were made to see directly the process that occurred by observing the activities carried out by studying the workings of the Bino Premium System at PT. Binokular Media Utama to seek information related to risk management from the use of information technology in the company and conducting risk management analysis on monitoring services used by the company.

2. Interviews were conducted to collect information and data by conducting direct questions and answers to trusted sources with IT Manager who has knowledge related to the Premium Bino System at PT. Binokular Media Utama. Direct interviews were carried out by taking into account the existing health protocols during the COVID-19 pandemic and if it was not possible to do so directly through social media such as WhatsApp. 
3. The questionnaire was conducted to collect data by giving a set of questions to respondents designed to determine the capability level of IT operational management that has been running at PT. Binokular Media Utama Yogyakarta. The questionnaire given to respondents is a written statement, the statement made refers to the COBIT 5 framework of the APO12 (Managing Risk) and EDM03 (Ensuring Risk Optimization) using the RACI Chart method which directly distinguishes work units based on the Stakeholder Job-description, so that the questionnaire will be validly accepted by the person in charge of IT services at PT. Binokular Media Utama.

\subsection{Implementation}

\subsubsection{Preparation of the Questionnaire}

The preparation of the questionnaire has been adapted to the COBIT 5 framework standards focusing on the APO12 (Managing Risk) process consisting of APO12.01 to APO12.06 and EDM03 (Ensuring Risk Optimization) consisting of EDM03.01 to EDM03.02. Questionnaires are used to assess the level of process capability in monitoring services at PT Binokular Media Utama.

\subsubsection{Determination of Respondents}

Determination of respondents through the RACI Chart has a function at the process level of responsibility for roles in the organizational structure of a company. The RACI Chart defines the authority of a person in an IT-based company. The RACI Chart that will be used is guided by the APO12 and EDM03 processes. The RACI Chart method which directly distinguishes work units based on the Stakeholder JobDescription, so that the questionnaire will be accepted legally by the person in charge of Monitoring Services at PT Binokular Media Utama.

Table 1. Results of Determination of Respondents RACI Chart APO12

\begin{tabular}{|c|l|l|c|}
\hline No & \multicolumn{1}{|c|}{$\begin{array}{c}\text { Structure of } \\
\text { COBIT 5 }\end{array}$} & $\begin{array}{l}\text { Organizational } \\
\text { Structure }\end{array}$ & ID \\
\hline 1 & $\begin{array}{l}\text { Business Process } \\
\text { Owners, Business } \\
\text { Continuity } \\
\text { Manager, Privacy } \\
\text { Officer, } \\
\text { Compliance }\end{array}$ & General \\
Manager & \\
\hline 2 & $\begin{array}{l}\text { Project } \\
\text { Management } \\
\text { Office, Service } \\
\text { Manager }\end{array}$ & $\begin{array}{l}\text { Production } \\
\text { Manager }\end{array}$ & R2 \\
\hline 3 & $\begin{array}{l}\text { Chief Risk } \\
\text { Officer, Chief } \\
\text { Information } \\
\text { Security Officer, } \\
\text { Head Architect, } \\
\text { Information } \\
\text { Security Manager, } \\
\text { Audit, Chief } \\
\text { Information } \\
\text { Officer }\end{array}$ & & \\
\hline 4 & Read & \\
\hline
\end{tabular}

\begin{tabular}{|c|l|l|l|}
\hline & Development & & \\
\hline 5 & Head IT & IT Coordinator & R5 \\
& $\begin{array}{l}\text { Operations, Head } \\
\text { IT Administration }\end{array}$ & DevOps & \\
\hline
\end{tabular}

Based on Table 1 determination of respondents using the APO12 domain process following RACI Chart COBIT 5 obtained 5 respondents. In table 1 respondents and positions in the company.

Table 2. Results of Determination of Respondents RACI Chart EDM03

\begin{tabular}{|c|l|l|c|}
\hline No & $\begin{array}{l}\text { Structure of } \\
\text { COBIT 5 }\end{array}$ & \multicolumn{1}{|c|}{$\begin{array}{c}\text { Organizational } \\
\text { Structure }\end{array}$} & ID \\
\hline 1 & $\begin{array}{l}\text { Chief Executive } \\
\text { Officer, } \\
\text { Business } \\
\text { Executives }\end{array}$ & General Manager & R1 \\
\hline 2 & $\begin{array}{l}\text { Strategy } \\
\text { Executive } \\
\text { Committee }\end{array}$ & $\begin{array}{l}\text { Production } \\
\text { Manager }\end{array}$ & R2 \\
\hline 3 & $\begin{array}{l}\text { Chief Risk } \\
\text { Officer, Chief } \\
\text { Information } \\
\text { Security Officer, } \\
\text { Chief } \\
\text { Information } \\
\text { Officer }\end{array}$ & IT Manager & \\
\hline
\end{tabular}

Based on Table 2 determination of respondents using the EDM03 domain process following RACI Chart COBIT 5 obtained 3 respondents. In table 2 respondents and positions in the company.

\subsubsection{Determination of Capability Level}

The results of determining the level of capability of the APO12 are based on the results of the calculation of the capability values contained in the APO12 sub-process.

Table 3. Determination of Capability Level APO12

\begin{tabular}{|c|l|c|c|}
\hline \multirow{2}{*}{ No } & \multirow{2}{*}{ Sub-process } & \multicolumn{2}{|c|}{ Capability Value } \\
\cline { 3 - 4 } & & Current & Expected \\
\hline 1 & APO12.01 & 4,11 & 4 \\
\hline 2 & APO12.02 & 3,83 & 4 \\
\hline 3 & APO12.03 & 3,26 & 4 \\
\hline 4 & APO12.04 & 3,72 & 4 \\
\hline 5 & APO12.05 & 2,93 & 4 \\
\hline 6 & APO12.06 & 3,8 & 4 \\
\hline \multicolumn{2}{|c|}{ Average } & 3,61 & 4 \\
\hline
\end{tabular}

Based on Table 3, it is known that the APO12 (Managing Risk) is at level 4 with a capability value of 3.61. At this level, the Bino Premium System Monitoring Service at PT Binokular Media Utama has implemented a Predictable Process. 
Table 4. Determination of Capability Level EDM03

\begin{tabular}{|c|l|c|c|}
\hline \multirow{2}{*}{ No } & Sub-process & \multicolumn{2}{|c|}{ Capability Value } \\
\cline { 3 - 4 } & & Current & Expected \\
\hline 1 & EDM03.01 & 3,4 & 4 \\
\hline 2 & EDM03.02 & 3,23 & 4 \\
\hline \multicolumn{2}{|c|}{ Average } & 3,32 & 4 \\
\hline
\end{tabular}

Based on Table 4, it is known that the EDM03 (Ensuring Risk Optimization) is at level 3 with a capability value of 3.32. At this level the Bino Premium System Monitoring Service at PT. Binokular Media Utama has implemented the Established Process.

\subsubsection{Process Achievements}

Process examination in the APO12 (Managing Risk) and EDM03 (Ensuring Risk Optimization) domains which aim to find out whether the requirements that must be met at each level are met with the provisions of the category from the results of the assessment at each level.

Table 5. APO12 PA 1.1 Process Performance

\begin{tabular}{|c|c|c|c|}
\hline $\begin{array}{c}\text { Work } \\
\text { Products }\end{array}$ & Description & Exist & Evidence \\
\hline $\begin{array}{l}\text { APO12- } \\
\text { WP1 }\end{array}$ & $\begin{array}{l}\text { Data on the } \\
\text { operating } \\
\text { environment } \\
\text { relating to risk }\end{array}$ & $\sqrt{ }$ & $\begin{array}{l}\text { Risk } \\
\text { Profile }\end{array}$ \\
\hline $\begin{array}{l}\text { APO12- } \\
\text { WP2 }\end{array}$ & $\begin{array}{ll}\begin{array}{l}\text { Data on risk } \\
\text { events }\end{array} & \begin{array}{l}\text { and } \\
\text { contributing }\end{array} \\
\text { factors } & \\
\end{array}$ & $\sqrt{ }$ & $\begin{array}{l}\text { Risk } \\
\text { Profile }\end{array}$ \\
\hline $\begin{array}{l}\text { APO12- } \\
\text { WP3 }\end{array}$ & $\begin{array}{l}\text { Emerging risk } \\
\text { issues and factors }\end{array}$ & $\sqrt{ }$ & $\begin{array}{c}\text { Risk } \\
\text { Profile }\end{array}$ \\
\hline $\begin{array}{l}\text { APO12- } \\
\text { WP4 }\end{array}$ & $\begin{array}{l}\text { Scope of risk } \\
\text { analysis efforts }\end{array}$ & $\sqrt{ }$ & $\begin{array}{l}\text { Risk } \\
\text { Profile }\end{array}$ \\
\hline $\begin{array}{l}\text { APO12- } \\
\text { WP5 }\end{array}$ & IT risk scenarios & $\sqrt{ }$ & $\begin{array}{c}\text { Risk } \\
\text { Profile }\end{array}$ \\
\hline $\begin{array}{l}\text { APO12- } \\
\text { WP6 }\end{array}$ & $\begin{array}{ll}\text { Risk } & \text { analysis } \\
\text { results }\end{array}$ & $\sqrt{ }$ & $\begin{array}{c}\text { Risk } \\
\text { Profile }\end{array}$ \\
\hline $\begin{array}{l}\text { APO12- } \\
\text { WP7 }\end{array}$ & $\begin{array}{l}\text { Documented risk } \\
\text { scenarios by line } \\
\text { of business and } \\
\text { function }\end{array}$ & $\sqrt{ }$ & $\begin{array}{c}\text { Risk } \\
\text { Profile }\end{array}$ \\
\hline $\begin{array}{l}\text { APO12- } \\
\text { WP8 }\end{array}$ & $\begin{array}{l}\text { Aggregated risk } \\
\text { profile, including } \\
\text { status of risk } \\
\text { management } \\
\text { actions }\end{array}$ & $\sqrt{ }$ & $\begin{array}{l}\text { Risk } \\
\text { Profile }\end{array}$ \\
\hline $\begin{array}{l}\text { APO12- } \\
\text { WP9 }\end{array}$ & $\begin{array}{l}\text { Risk analysis and } \\
\text { risk profile } \\
\text { reports } \\
\text { stakeholders }\end{array}$ & $\sqrt{ }$ & $\begin{array}{c}\text { Evaluation } \\
\text { Report }\end{array}$ \\
\hline $\begin{array}{l}\text { APO12- } \\
\text { WP10 }\end{array}$ & \begin{tabular}{lr}
\multicolumn{2}{l}{ Review results of } \\
third-party risk \\
assessments
\end{tabular} & - & - \\
\hline $\begin{array}{l}\text { APO12- } \\
\text { WP11 }\end{array}$ & 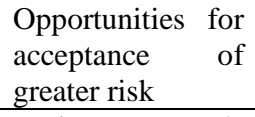 & $\sqrt{ }$ & $\begin{array}{l}\text { Risk } \\
\text { Profile }\end{array}$ \\
\hline $\begin{array}{l}\text { APO12- } \\
\text { WP12 }\end{array}$ & $\begin{array}{l}\text { Project proposals } \\
\text { for reducing risk }\end{array}$ & $\sqrt{ }$ & $\begin{array}{l}\text { Risk } \\
\text { Profile }\end{array}$ \\
\hline $\begin{array}{l}\text { APO12- } \\
\text { WP13 }\end{array}$ & $\begin{array}{l}\text { Risk-related } \\
\text { incident response }\end{array}$ & $\sqrt{ }$ & $\begin{array}{l}\text { Risk } \\
\text { Profile }\end{array}$ \\
\hline
\end{tabular}

\begin{tabular}{|c|l|c|c|}
\hline & plans & & \\
\hline $\begin{array}{c}\text { APO12- } \\
\text { WP14 }\end{array}$ & $\begin{array}{l}\text { Risk impact } \\
\text { communications }\end{array}$ & $\sqrt{ }$ & $\begin{array}{c}\text { Risk } \\
\text { Profile }\end{array}$ \\
\hline $\begin{array}{c}\text { APO12- } \\
\text { WP15 }\end{array}$ & $\begin{array}{l}\text { Risk-related root } \\
\text { causes }\end{array}$ & $\sqrt{ }$ & $\begin{array}{c}\text { Risk } \\
\text { Profile }\end{array}$ \\
\hline \multicolumn{2}{|c|}{ Average Score } & $93,33 \%$ \\
\hline
\end{tabular}

Based on Table 5 the achievement of the APO12 process on the Bino Premium System Monitoring Service at PT. Binokular Media Utama to meet process attributes in process capabilities at level 1 Process Performance.

Table 6. EDM03 PA 1.1 Process Performance

\begin{tabular}{|c|c|c|c|}
\hline $\begin{array}{c}\text { Work } \\
\text { Products }\end{array}$ & Description & Exist & Evidence \\
\hline $\begin{array}{l}\text { EDM03- } \\
\text { WP1 }\end{array}$ & $\begin{array}{l}\text { Risk appetite } \\
\text { guidance }\end{array}$ & $\sqrt{ }$ & $\begin{array}{c}\text { IT } \\
\text { Knowledge } \\
\text { Base } \\
\end{array}$ \\
\hline $\begin{array}{l}\text { EDM03- } \\
\text { WP2 }\end{array}$ & $\begin{array}{l}\text { Approved risk } \\
\text { tolerance levels }\end{array}$ & $\sqrt{ }$ & $\begin{array}{c}\text { IT } \\
\text { Knowledge } \\
\text { Base }\end{array}$ \\
\hline $\begin{array}{l}\text { EDM03- } \\
\text { WP3 }\end{array}$ & $\begin{array}{l}\text { Evaluation of } \\
\text { risk } \\
\text { management } \\
\text { activities }\end{array}$ & $\sqrt{ }$ & $\begin{array}{c}\text { Evaluation } \\
\text { Report }\end{array}$ \\
\hline $\begin{array}{l}\text { EDM03- } \\
\text { WP4 }\end{array}$ & $\begin{array}{l}\text { Risk } \\
\text { management } \\
\text { policies }\end{array}$ & $\sqrt{ }$ & $\begin{array}{c}\text { IT } \\
\text { Knowledge } \\
\text { Base }\end{array}$ \\
\hline $\begin{array}{l}\text { EDM03- } \\
\text { WP5 }\end{array}$ & $\begin{array}{l}\text { Key objectives } \\
\text { to be monitored } \\
\text { for risk } \\
\text { management }\end{array}$ & $\sqrt{ }$ & $\begin{array}{c}\text { IT } \\
\text { Knowledge } \\
\text { Base }\end{array}$ \\
\hline $\begin{array}{l}\text { EDM03- } \\
\text { WP6 }\end{array}$ & $\begin{array}{l}\text { Approved } \\
\text { process for } \\
\text { measuring risk } \\
\text { management }\end{array}$ & $\sqrt{ }$ & $\begin{array}{c}\text { IT } \\
\text { Knowledge } \\
\text { Base }\end{array}$ \\
\hline $\begin{array}{l}\text { EDM03- } \\
\text { WP7 }\end{array}$ & $\begin{array}{l}\text { Remedial } \\
\text { actions to } \\
\text { address risk } \\
\text { management } \\
\text { deviations }\end{array}$ & $\sqrt{ }$ & Risk Profile \\
\hline $\begin{array}{l}\text { EDM03- } \\
\text { WP8 }\end{array}$ & $\begin{array}{l}\text { Risk } \\
\text { management } \\
\text { issues for the } \\
\text { board }\end{array}$ & $\sqrt{ }$ & Risk Profile \\
\hline \multicolumn{2}{|c|}{ Average Score } & \multicolumn{2}{|c|}{$100 \%$} \\
\hline
\end{tabular}

Based on Table 6 the achievement of the EDM03 process on the Bino Premium System Monitoring Service at PT. Binokular Media Utama to meet process attributes in process capability at level 1 Process Performance.

\subsubsection{Gap and Recommendation APO12}

The results of the calculation of the value of the APO12 process gap (Managing Risk) that have been obtained from the results of the questionnaire were analyzed based on each question in the sub-process and then compared with the results of observations and interviews. The results of the assessment of each process will be made recommendations as improvements so that the expected conditions can be achieved and improved for the better by PT Binokular Media Utama adjusted to the COBIT 5 framework. 
Table 7. Capability Level in Process APO12

\begin{tabular}{|c|c|c|c|c|c|}
\hline No & \multirow{2}{*}{$\begin{array}{c}\text { Sub- } \\
\text { process }\end{array}$} & \multicolumn{2}{|c|}{ Capability Level } & \multirow{2}{*}{ Max } & Gap \\
\cline { 3 - 4 } & & Current & Expected & & \\
\hline 1 & APO12.01 & 4 & 4 & 5 & 0 \\
\hline 2 & APO12.02 & 4 & 4 & 5 & 0 \\
\hline 3 & APO12.03 & 3 & 4 & 5 & 1 \\
\hline 4 & APO12.04 & 4 & 4 & 5 & 0 \\
\hline 5 & APO12.05 & 3 & 4 & 5 & 1 \\
\hline 6 & APO12.06 & 4 & 4 & 5 & 0 \\
\hline \multicolumn{7}{|l}{ Average } & 3,67 & 4 & 5 & 0,33 \\
\hline
\end{tabular}

Based on Table 7 the current capability level value is at level 4 and the expected capability level value is 3,67 so that the resulting gap from the APO12 process is 0,33 which will be given recommendations as described in the process attribute following current company needs.

Table 8. Recommendations APO12

\begin{tabular}{|c|c|c|}
\hline \multicolumn{3}{|c|}{ APO12 Manage Risk } \\
\hline Sub-process & & Recommendation \\
\hline $\begin{array}{l}\text { APO12.01 } \\
\text { (Collect } \\
\text { Data) }\end{array}$ & a. & $\begin{array}{l}\text { Monitoring services at PT } \\
\text { Binocular Media Utama that } \\
\text { are already running must } \\
\text { continue to be improved in data } \\
\text { collection, classification and } \\
\text { analysis to make it easier to } \\
\text { manage data in print, online } \\
\text { and broadcast media. } \\
\text { Monitoring services at PT } \\
\text { Binocular Media Utama that } \\
\text { are already running must } \\
\text { continue to be improved in data } \\
\text { recording in the internal and } \\
\text { external operating environment } \\
\text { when managing video and } \\
\text { audio recordings, adding data } \\
\text { storage periodically to make it } \\
\text { even better. }\end{array}$ \\
\hline $\begin{array}{l}\text { APO12.02 } \\
\text { (Analyse } \\
\text { Risk) }\end{array}$ & & $\begin{array}{l}\text { Monitoring services at PT } \\
\text { Binokular Media Utama that } \\
\text { are already running must } \\
\text { continue to be improved in risk } \\
\text { analysis, risk factors and asset- } \\
\text { related criticism that can } \\
\text { interfere with the operational } \\
\text { activities of Bino Premium } \\
\text { products. } \\
\text { Monitoring services at PT } \\
\text { Binocular Media Utama, which } \\
\text { are already running, must } \\
\text { continue to be improved in } \\
\text { terms of updating, controlling } \\
\text { and detecting risk by } \\
\text { performing risk mitigation }\end{array}$ \\
\hline
\end{tabular}

\begin{tabular}{|c|c|c|}
\hline & & which is always monitored. \\
\hline $\begin{array}{l}\text { APO12.03 } \\
\text { (Maintain a } \\
\text { Risk Profile) }\end{array}$ & a. & $\begin{array}{l}\text { Monitoring services at PT } \\
\text { Binokular Media Utama, which } \\
\text { are already running, need to } \\
\text { manage business processes } \\
\text { including services, facilities } \\
\text { and document IT services that } \\
\text { can be accessed through the } \\
\text { system so that they are } \\
\text { monitored regularly in order to } \\
\text { provide effective and efficient } \\
\text { services. } \\
\text { Monitoring services at PT } \\
\text { Binocular Media Utama that } \\
\text { are already running need to be } \\
\text { regulated and approved for IT } \\
\text { services to maintain the running } \\
\text { of business processes that are } \\
\text { useful in providing fast and } \\
\text { accurate data and information } \\
\text { to support the company's } \\
\text { business processes. }\end{array}$ \\
\hline $\begin{array}{l}\text { APO12.04 } \\
\text { (Articulate } \\
\text { Risk) }\end{array}$ & a. & $\begin{array}{l}\text { Monitoring services at PT } \\
\text { Binocular Media Utama that } \\
\text { are already running must } \\
\text { continue to be improved in } \\
\text { reporting the results of risk } \\
\text { analysis to stakeholders as a } \\
\text { record of finding problems that } \\
\text { have occurred so that the } \\
\text { measurement results can be } \\
\text { applied so that there are } \\
\text { developments and positive } \\
\text { impacts for the company. } \\
\text { Monitoring services at PT } \\
\text { Binocular Media Utama that } \\
\text { are already running must } \\
\text { continue to be improved in } \\
\text { making decisions to understand } \\
\text { the worst risks by looking at } \\
\text { and ensuring the resources that } \\
\text { have been used are effective or } \\
\text { not so far in detail. }\end{array}$ \\
\hline $\begin{array}{l}\text { APO12.05 } \\
\text { (Define a } \\
\text { Risk } \\
\text { Management } \\
\text { Action } \\
\text { Portfolio) }\end{array}$ & & $\begin{array}{l}\text { Monitoring services at PT } \\
\text { Binocular Media Utama, which } \\
\text { are already running, need to } \\
\text { control risk management } \\
\text { through a collection of } \\
\text { quantitative measurement } \\
\text { results that the company uses to } \\
\text { measure performance in an } \\
\text { effort to meet the company's } \\
\text { strategic and operational } \\
\text { objectives. } \\
\text { Monitoring services at PT } \\
\text { Binocular Media Utama, which } \\
\text { are already running, need to be } \\
\text { carried out by the company to }\end{array}$ \\
\hline
\end{tabular}




\begin{tabular}{|c|c|c|}
\hline & & $\begin{array}{l}\text { monitor risk within the } \\
\text { tolerance level of individuals } \\
\text { and portfolios using existing } \\
\text { performance reviews in the } \\
\text { company to assess subjectively } \\
\text { according to the company's } \\
\text { productivity. }\end{array}$ \\
\hline $\begin{array}{l}\text { APO12.06 } \\
\text { (Respond to } \\
\text { Risk) }\end{array}$ & & $\begin{array}{l}\text { Monitoring services at PT } \\
\text { Binocular Media Utama that } \\
\text { are already running must } \\
\text { continue to be improved in } \\
\text { documenting the steps that } \\
\text { must be taken during risk } \\
\text { events by addressing them } \\
\text { according to company SOPs } \\
\text { and adjusting to the conditions } \\
\text { of the print, online and } \\
\text { broadcast media. } \\
\text { Monitoring services at PT } \\
\text { Binocular Media Utama that } \\
\text { are already running must } \\
\text { continue to be improved in risk } \\
\text { management in accordance } \\
\text { with the risk tolerance } \\
\text { threshold so that companies can } \\
\text { use the concept of } \\
\text { microservices. }\end{array}$ \\
\hline
\end{tabular}

Based on Table 8 , some gaps must be met by the Bino Premium System Monitoring Service at PT Binokular Media Utama to meet the requirements at level 4 (Predictable Process) in the APO12 process.

\subsubsection{Gap and Recommendation EDM03}

The results of the calculation of the EDM03 process gap value (Ensuring Risk Optimization) that have been obtained from the results of the questionnaire which were analyzed based on each question in the sub-process are then compared with the results of observations and interviews.

Table 9. Capability Level in Process EDM03

\begin{tabular}{|c|l|c|c|c|c|}
\hline \multirow{2}{*}{ No } & $\begin{array}{c}\text { Sub- } \\
\text { process }\end{array}$ & \multicolumn{2}{|c|}{ Capability Level } & Max & Gap \\
\cline { 3 - 4 } & & Current & Expected & & \\
\hline 1 & EDM03.01 & 3 & 4 & 5 & 1 \\
\hline 2 & EDM03.02 & 3 & 4 & 5 & 1 \\
\hline \multicolumn{2}{|c|}{ Average } & 3 & 4 & 5 & 1 \\
\hline
\end{tabular}

Based on Table 9 the current capability level value is at level 3 and the expected capability level value is 3 so that the gap resulting from the EDM03 process is 1 which will be recommended following what is described in the process attribute according to the company's current needs.

Table 10. Gaps and Recommendations EDM03

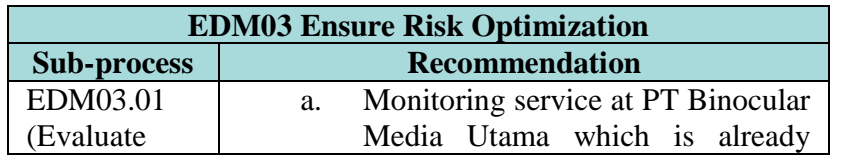

\begin{tabular}{|c|c|c|}
\hline $\begin{array}{l}\text { Risk } \\
\text { Management) }\end{array}$ & b. & $\begin{array}{l}\text { running, it is necessary to } \\
\text { determine the level of risk by } \\
\text { activating other services when } \\
\text { experiencing disruptions and } \\
\text { applying rotation related to certain } \\
\text { services to achieve company goals. } \\
\text { Monitoring services at PT } \\
\text { Binocular Media Utama that are } \\
\text { already running need to be } \\
\text { evaluated and approved for the } \\
\text { level of risk so that it can be } \\
\text { accepted by the company by } \\
\text { reviewing the print, online and } \\
\text { broadcast media operations } \\
\text { according to needs. }\end{array}$ \\
\hline $\begin{array}{l}\text { EDM03.02 } \\
\text { (Direct Risk } \\
\text { Management) }\end{array}$ & a. & $\begin{array}{l}\text { Monitoring services at PT } \\
\text { Binocular Media Utama, which are } \\
\text { already running, need to increase } \\
\text { risk awareness by identifying risks } \\
\text { that have occurred and making } \\
\text { notes regarding various problems } \\
\text { that occur so that they do not recur. } \\
\text { Monitoring services at PT } \\
\text { Binokular Media Utama, which are } \\
\text { already running, need to be briefed } \\
\text { on the integration between strategy } \\
\text { and risk operations with routine } \\
\text { cloud data collection so that they } \\
\text { can find out the right time to resize } \\
\text { and not interfere with operational } \\
\text { activities. }\end{array}$ \\
\hline
\end{tabular}

Based on Table 10, some gaps must be met by the Bino Premium System Monitoring Service at PT. Binokular Media Utama to meet the requirements at level 3 (Established Process) in the EDM03 process.

\section{CONCLUSION}

Based on the results of the risk management analysis carried out in this study with the title "Risk Management Analysis of Monitoring Services Using COBIT 5 Framework" by assessing the level of process capability in the Premium Bino System Monitoring Service at PT Binokular Media Utama using the COBIT 5 framework. Assessment of the current process capability level based on calculations carried out using the APO12 (Manage Risk) domain, the average value is obtained at level 4 (Predictable Process) with a capability value of 3,67 and EDM03 (Ensure Risk Optimization) the average value is obtained at level 3 (Established Process) with a capability value of 3 . The results of the GAP (gap) value based on calculations performed using the APO12 (Manage Risk) domain found a Gap of 0,33 and EDM03 (Ensure Risk Optimization) found a Gap of 1 . The results of the analysis carried out obtained recommendations given for Monitoring Services to improve processes that are already running at PT. Binokular Media Utama.

\section{REFERENCES}

[1] Aziz, A. R., Kusrini., \& Sudarmawa. (2018). 'Evaluation of Information Technology Risk Management in StateOwned Enterprises Using the COBIT 5 Standard (Case Study: PT TASPEN PERSERO)', IT Journal CIDA, Vol. 4, No. 2, December 2018, ISSN: 2477-8133, e-ISSN: 2477-8125. 
[2] Darmawan, K. S., \& Dwiharto, A. (2019). 'Measurement of Capability Level of E-Government Service Quality in Pamekasan Regency Using the COBIT 5.0 Framework', INTENSIF, Vol. 3, No. 2, August 2019, ISSN: 2580$409 \mathrm{X}$ (Print) / 2549-6824 (Online), DOI: https://doi.org/10.29407/intensif.v3i2.12659.

[3] Elly., \& Halim, F. (2021). 'IT Infrastructure Governance Evaluation With COBIT 5 Framework', Journal of Information Systems, SMIK Mikroskil.

[4] Febriani, F., \& Manuputty D. A. (2021). 'Evaluation of Governance to Improve Information Technology Management Performance Using the COBIT 5 Framework', Journal of Informatics and Information Systems Engineering, Vol. 7, No. 1, April 2021.

[5] Firdaus, S. K. M. (2018). Evaluation of Information Technology Risk Management Using the COBIT 5 Framework.

[6] Fuad, M. N. (2020). Risk Management Assessment in UAD HR Information Technology Services Using the COBIT 5 Method.

[7] Hantoro, N. Y., \&Widodo, Suryarini. (2021). 'Evaluation of Information Technology Governance at the Bogor Regency Manpower Office Using the Process Assessment Model (PAM)', Scientific Journal of Computer Informatics, Vol. 26, No. 1, April 2021.

[8] Ichwani, A., \& Farida, D. A. (2020). 'Measurement of the Risk Management Capability Level of Sharia Cooperative Information Systems Using the COBIT 5 Framework', Computing Journal, Vol. 8, No. 1, 2020.

[9] Irawan, D. M., Seraya, A., Amalia, N., \& Arifianda, R. R. (2020). 'Implementation of Cobit 5 in Information Technology Governance Evaluation', Journal of Information Systems and Applications Technology, Vol. 3, No. 4, October 2020.

[10] ISACA. (2012). COBIT 5: A Business Framework for The Governance and Management of Enterprise IT.

[11] ISACA. (2012). COBIT 5: Enabling Processes.

[12] ISACA. (2012). COBIT 5: Implementation.

[13] ISACA. (2012). COBIT 5: Process Assessment Model (PAM): Using COBIT 5.

[14] Khairuna, D., Wibowo, S., \& Gamayanto, I. (2020). 'Evaluation of Information Technology Risk Management Using COBIT 5 Framework Based on Domain APO12 (Manage Risk) at the Head Office of BPR Agung Sejahtera', Journal of Information System, Vol. 5, No. 1, Mei 2020: 18-26 DOI: 10.33633/joinsv5i1.3088.

[15] Lamanto, S. M., Setyanto, A., \& Nasiri, A. (2019). 'Evaluation of Maturity Level of IT Infrastructure
Governance Using COBIT 5', Journal of Information Systems and Information Technology, Vol. 8, No. 2, October 2019.

[16] Mutiah, N. (2019). 'Tanjungpura University Information Technology Governance Assessment Using COBIT 5 Domain APO', Journal of Computer Engineering, Vol. 4, No. 1, January 2019.

[17] Nurhidayat, R., \& Handayaningsih, S. (2019). 'Analysis of Risk Management in Student Resignation Services Using the COBIT 5 Framework Focuses on Managing Risk (APO12)', Journal of Bachelor of Informatics Engineering, e-ISSN 2338-5197, Vol. 7, No. 1, February 2019, pp. 69-76.

[18] Oktaviani, M. C., \& Adnan, N. F. (2019). 'SelfAssessment of Problem Management at SIADIN Dian Nuswantoro University Based on COBIT 5', Journal of Information Systems, Vol. 4, No. 1, May 2019.

[19] Prastiyawan, A. D., Ambarwati, A., \& Setiawan, E. (2020). 'Risk Management Analysis Dealer Management System Services Using COBIT 5', MATRIX JOURNAL, VOL. 10, NO. 2, July 2020.

[20] Putri, I. Y., Suprapto., \& Herlambang, D. A. (2018) 'Assessment of the Capability of Implementing Information Technology Risk Management Using the COBIT 5 Framework (Study on PDAM Malang City, East Java)', Journal of Information Technology and Computer Science Development, e-ISSN: 2548-964X, Vol. 2, No. 11, November 2018, hlm. 4855-4862.

[21] Rabhani, P. A., Maharani A., \& Putrie A. A. (2020) 'Attendance Information System Audit at the Bandung City Public Prosecutor's Office Using the COBIT 5 'Framework, Journal of Information Systems and Computers, Vol. 9, No.2, Agustus 2020.

[22] Sarmini., \& Adipurwoko P. S. (2019). 'Ensure Risk Optimization of Information Technology Implementation Using the COBIT 5' Framework, SIMETRIS Journal, Vol. 10, No. 2, November 2019, P-ISSN: 2252-4983, EISSN: 2549-3108.

[23] Thenu, P. P., Wijaya, F. A., \& Rudianto C. (2020). 'Information Technology Risk Management Analysis Using COBIT 5 (case study: PT GLOBAL INFOTECH)', Journal of Computer Development JBK, Vol. 2, No. 1, February 2020: 1-13

[24] Triyanto, T., \& Gata, W. (2018). 'Maturity Level Information Management Using COBIT 5 in Program and Project Management Case Study PT. XYZ', Gateway Journal, Vol. 8, No. 1, February 2018.

[25] Yusuf, Y., Gunawan T. E., \& Sarita, R. (2021). 'Analysis of Service Maturity Levels at PT Telkom Sampit Using COBIT 5 Domains DDS02 and DSS03' Journal of Information Systems, Vol. 2, No. 4, July 2021. 